\title{
Protective Effects of Ambient Ozone on Incidence and Outcomes of Ischemic Stroke in Changzhou, China: A Time-Series Study
}

\author{
Yongquan Yu ${ }^{1, \dagger}$, Huibin Dong ${ }^{2, \dagger}$, Shen Yao ${ }^{1}$, Minghui $\mathrm{Ji}^{1}{ }^{1}$, Xingjuan Yao ${ }^{2}$ and Zhan Zhang ${ }^{3, *}$ \\ 1 Department of Occupational Medicine and Environmental Health, School of Public Health, \\ Nanjing Medical University, 101 Longmian Avenue, Nanjing 211166, China; yyqaion@sina.com (Y.Y.); \\ 13814128712@163.com (S.Y.); jiminghui77@sina.com (M.J.) \\ 2 Department of Chronic Disease Control and Prevention, Changzhou Center for Disease Control and \\ Prevention, 203 Taishan Road, Changzhou 213022, China; huibind@126.com (H.D.); myaoxj@163.com (X.Y.) \\ 3 Department of Hygiene Analysis and Detection, School of Public Health, Nanjing Medical University, \\ 101 Longmian Avenue, Nanjing 211166, China \\ * Correspondence: zhanzhang@njmu.edu.cn; Tel.: +86-258-686-8402; Fax: +86-258-686-8499 \\ + These authors contributed equally to this work.
}

Received: 2 November 2017; Accepted: 19 December 2017; Published: 20 December 2017

\begin{abstract}
The potential beneficial effect of ozone $\left(\mathrm{O}_{3}\right)$ on stroke had been identified experimentally and clinically, but these effects remain controversial in population-based studies. This study aimed to explore the epidemiological association between $\mathrm{O}_{3}$ and risk of ischemic stroke. Ischemic stroke related health data and air pollution data were obtained from the Center for Disease Control and Prevention and Environmental Monitoring Center in Changzhou between 2015 and 2016, respectively. The associations between the short-term exposure to $\mathrm{O}_{3}$ and daily ischemic stroke onsets and deaths were examined based on time-series generalized additive Poisson model. During the study period, daily ischemic stroke onsets and deaths decreased $0.340 \%$ (95\% confidence interval (CI) $-0.559 \%$ to $-0.120 \%$ ) and $0.697 \%(95 \% \mathrm{CI}-1.103 \%$ to $-0.290 \%)$ with an interquartile range (IQR) $\left(41.1 \mu \mathrm{g} / \mathrm{m}^{3}\right)$ increase in levels of ambient $\mathrm{O}_{3}$, respectively. The protective effects of $\mathrm{O}_{3}$ were more significant in men and elders and in the cool season than those in women and young people and in the warm season, respectively. The negative association was independent of $\mathrm{PM}_{2.5}, \mathrm{PM}_{10}, \mathrm{SO}_{2}, \mathrm{NO}_{2}$ or $\mathrm{CO}$ exposure. Acute $\mathrm{O}_{3}$ exposure was associated with decreased risk of ischemic stroke. These findings will help provide new insights into the relationship between ischemic stroke and ambient $\mathrm{O}_{3}$ concentrations.
\end{abstract}

Keywords: ozone; ischemic stroke; time-series study; generalized additive model

\section{Introduction}

Stroke is the leading cause of death and disability-adjusted life years worldwide; approximately 16.9 million new stroke cases and 5.9 million stroke related deaths occurred in 2010 [1-3]. Ischemic stroke occurs when a blood vessel carrying blood to the brain is blocked by arterial thrombosis or embolism [4]. It is the major subtype of stroke (accounting for approximately $80 \%$ of all strokes) and can result in neurologic cell death and dysfunction [4,5]. Due to the enormous disease burden of ischemic stroke, numerous studies were conducted to detect the modifiable risk factors for ischemic stroke, including potentially deleterious air pollutants [6,7]. A cohort study in Hong Kong found that exposure to fine particulate matter (PM) with aerodynamic diameter less than $2.5 \mu \mathrm{m}\left(\mathrm{PM}_{2.5}\right)$ were associated with higher risk of ischemic stroke [8]. An interquartile range (IQR) increase in daily average levels of $\mathrm{PM}_{10}$ was also positively associated with a $0.8 \%$ increase in ischemic stroke admissions [9]. Moreover, short-term increments in gaseous pollutants such as nitrogen dioxide $\left(\mathrm{NO}_{2}\right)$, sulfur dioxide 
$\left(\mathrm{SO}_{2}\right)$ and carbon monoxide $(\mathrm{CO})$ were found to be associated with higher ischemic stroke risk $[10,11]$. However, only a few researches have observed the cerebrovascular effect of ozone $\left(\mathrm{O}_{3}\right)$ and the results were controversial. Few of them found statistical positive associations between risk of ischemic stroke and daily $\mathrm{O}_{3}$ concentrations [12], while others found no significant associations [13,14]. Thus, it is an urgent need to document the relationship between ambient $\mathrm{O}_{3}$ levels and risk for ischemic stroke.

Ground-level $\mathrm{O}_{3}$ is a pale blue secondary pollutant, which is created by the action of ultraviolet rays on precursors such as combustion of fossil fuels and methane [15]. However, under certain circumstance, $\mathrm{O}_{3}$ may also serve as a 'protector' against cerebral damage. $\mathrm{O}_{3}$ major auto-hemo-therapy has been used in the treatment of ischemic disorders [16]. Oxygen-ozone gaseous mixture appeared to be effective in reverting damage of brain tissues [17]. It also can exert neuroprotective effects by regulating inflammatory response, improving cerebrovascular rheology and strengthening antioxidant in hypoxic brains [18].

In the current study, a time-series analysis was conducted to examine the associations between the short-term increment in ambient $\mathrm{O}_{3}$ concentrations and daily ischemic stroke onsets and deaths in Changzhou. Two-pollutant and multi-pollutant models were used to control the confounding pollutants. Sub-group analysis was conducted to explore the effect modification and screen the sensitive subpopulations. Acute $\mathrm{O}_{3}$ exposure was associated with decreased risk of ischemic stroke. This study will help provide new insights into the correlation between ischemic stroke and ambient $\mathrm{O}_{3}$ exposure.

\section{Materials and Methods}

\subsection{Data Collection}

Data on daily onsets and deaths for ischemic stroke were collected from cardio-cerebrovascular disease reporting system of Changzhou between 9 January 2015 and 31 December 2016. The diagnosis of ischemic stroke was on the basis of The International Classification of Diseases, Revision 10 (ICD-10) codes for ischemic stroke (I63). There were approximately 45.4 ischemic stroke cases (32,840 in total) and 5.6 ischemic stroke deaths (4028 in total) identified each day. The daily ischemic stroke counts and deaths were further stratified into groups by sex, age (young people $<65$ years and elders $\geq 65$ years) and season (warm season as 1 May to 31 October and cold season as 1 November to 30 April). For the daily ischemic stroke counts, the average number in male and elder was 23.7 and 36.9, respectively. For daily ischemic stroke deaths, the average number in male and elder was 2.7 and 5.1, respectively.

Daily mean levels for ambient $\mathrm{O}_{3}\left(90.7 \mu \mathrm{g} / \mathrm{m}^{3}, 8 \mathrm{~h}\right.$ max $)$ and other air pollutants such as $\mathrm{PM}_{2.5}$ $\left(51.8 \mu \mathrm{g} / \mathrm{m}^{3}\right), \mathrm{PM}_{10}\left(85.3 \mu \mathrm{g} / \mathrm{m}^{3}\right), \mathrm{NO}_{2}\left(22.3 \mu \mathrm{g} / \mathrm{m}^{3}\right), \mathrm{SO}_{2}\left(38.7 \mu \mathrm{g} / \mathrm{m}^{3}\right)$ and $\mathrm{CO}\left(1 \mathrm{mg} / \mathrm{m}^{3}\right)$ were collected from the database of Changzhou Environmental Monitoring Center (EMC) from 9 January 2015 to 31 December 2016. The average daily temperature and relative humidity was $17.0^{\circ} \mathrm{C}$ and $75 \%$, respectively. A total of six state-controlled, two province-controlled and two city-controlled air quality monitoring stations were established to comprehensively record the variation of air pollutants levels. The air pollution concentrations used in this study were averaged from all the stations as they all represented the urban background air pollution levels. Moreover, the fixed-site air pollution data might be a good proxy for personal exposure as all the ischemic stroke patients and deaths were resided less than $40 \mathrm{~km}$ from the nearest station [19]. The present study was approved by the Institutional Review Board of Changzhou Center for Disease Control and Prevention, and all procedures were in accordance with prevailing ethical principles (ethnical code: 2016-01).

\subsection{Statistical Analysis}

Daily data for air pollutants levels and weather conditions were pooled together for the same time to match the daily ischemic stroke onsets and deaths. A longitudinal time-series design was conducted to evaluate the associations between the short-term expose to $\mathrm{O}_{3}$ and daily ischemic stroke onsets and 
deaths. Generalized additive model (GAM) with Poisson regression was used to calculate data and multivariable regression model was used to control the potential confounding factors:

$$
\begin{gathered}
\log \left[E\left(T_{d n}\right)\right]=\quad \text { intercept }+\beta_{1} O_{3(n-i)}+\beta_{2} D O W+p s(\text { calender time, } d f=7)+p s\left(\text { Temp }_{n-i}, d f=5\right) \\
+p s(\text { Relatuve Humidiy } \\
n-i, d f=5)
\end{gathered}
$$

where $E\left(T_{d n}\right)$ was the expected daily numbers of ischemic stroke onsets or deaths on day $\mathrm{n} ; \mathrm{O}_{3(n-i)}$ was the daily mean levels of $\mathrm{O}_{3}$ on day $\mathrm{n}$ and $\mathrm{i}$ was the day lag; $\beta$ was vector of the coefficients; DOW was the day of week; $p s$ () meant penalized spline function; Temp $p_{n-i}$ and Relative Humidity ${ }_{n-i}$ meant average temperature and relative humidity on day $n$ and $i$ represented the day lag.

To detect the possible lagged effects that may occur, lag models were used with different lag days (lag 0 , lag 1, lag 3 and lag 5). Furthermore, the moving average levels of $\mathrm{O}_{3}$ during $0-1$ days (lag 0-1), $0-3$ days (lag $0-3$ ) and $0-5$ days (lag $0-5$ ) were detected to comprehensively evaluate the effects. Two-pollutant models by respectively adjusting $\mathrm{PM}_{2.5}, \mathrm{PM}_{10}, \mathrm{NO}_{2}, \mathrm{SO}_{2}$ and $\mathrm{CO}$ levels and multi-pollutant model by adding all the pollutants were conducted for the subsequent sensitivity analysis. Smoothing function was also used to graphically analyze the exposure-response association between daily $\mathrm{O}_{3}$ levels and log-relative risk of daily ischemic stroke onsets or deaths with a $5 \mathrm{df}$ in single-pollutant model.

Statistical software R (version 3.2.3, R Foundation for Statistical Computing, Vienna, Austria) was used for data analysis and result output. The baseline data were presented as mean \pm standard deviation (SD) for continuous variables. All tests were two-sided, and $p<0.05$ was considered as statistically significant.

\section{Results}

The monthly distribution patterns of $\mathrm{O}_{3}$ and other ambient pollutants $\left(\mathrm{PM}_{2.5}, \mathrm{PM}_{10}, \mathrm{SO}_{2}, \mathrm{NO}_{2}\right.$ and $\mathrm{CO}$ ) were illustrated in Figure 1. The concentration of $\mathrm{O}_{3}$ was higher in warm seasons than in cool seasons (Figure 1A), whereas the concentrations of $\mathrm{PM}_{2.5}$ (Figure 1B), $\mathrm{PM}_{10}$ (Figure 1C), $\mathrm{NO}_{2}$ (Figure 1D), $\mathrm{SO}_{2}$ (Figure 1E), and $\mathrm{CO}$ (Figure 1F) were higher in cool seasons than in warm seasons.

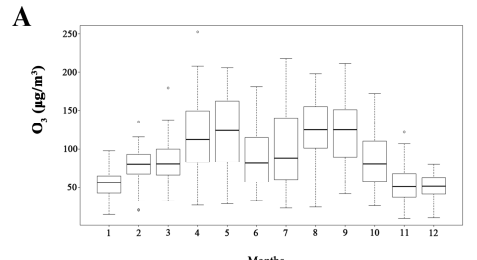

c
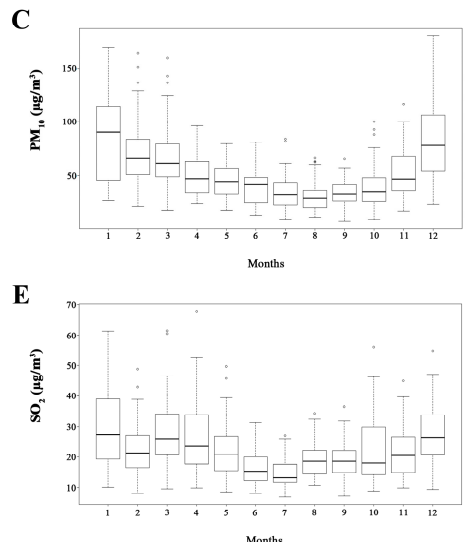

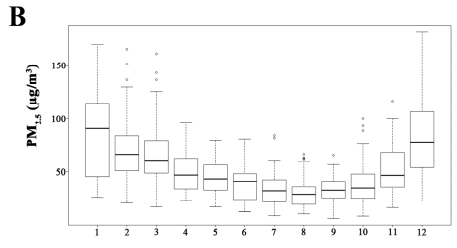

D
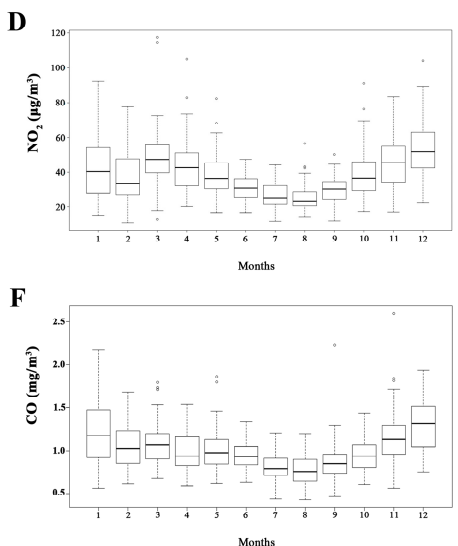

Figure 1. Monthly distribution patterns of ambient pollutants in Changzhou, 2015-2016. (A) $\mathrm{O}_{3}$ indicates ozone; (B) $\mathrm{PM}_{2.5}$, particulate matter that is $\leq 2.5 \mu \mathrm{m}$ in diameter; $(\mathrm{C}) \mathrm{PM}_{10}$, particulate matter that is $\leq 10 \mu \mathrm{m}$ in diameter; (D) $\mathrm{NO}_{2}$, nitrogen dioxide; (E) $\mathrm{SO}_{2}$, sulfur dioxide; (F) $\mathrm{CO}$, carbon monoxide. 
The results of the single-pollutant model for daily ischemic stroke onsets and deaths were summarized in Figure 2. Statistical percent decreases (95\% confidence interval (CI)) were observed in daily ischemic stroke onsets with an interquartile range (IQR) $\left(41.1 \mu \mathrm{g} / \mathrm{m}^{3}\right)$ increase in $\mathrm{O}_{3}$ concentrations for lag $3(-0.220 \%, 95 \%$ CI $-0.367 \%$ to $-0.072 \%)$, lag $5(-0.278 \%, 95 \%$ CI $-0.421 \%$ to $-0.134 \%)$ and lag $0-5(-0.340 \%, 95 \% \mathrm{CI}-0.559 \%$ to $-0.120 \%)$ days and the association was more pronounced for lag $0-5$ than lag 3 and lag 5 (Figure 2A). Therefore, lag $0-5$ was used in the subsequent analysis. Negative association was also found between $\mathrm{O}_{3}$ levels and daily ischemic stroke deaths with a 5 day lag (lag 5). An IQR increment of $\mathrm{O}_{3}$ corresponded to $0.9 \%$ decrease of daily ischemic stroke deaths. No statistical association was observed at other lag days (Figure 2B).

Subgroup analyses modifying by age, gender and seasons were presented in Table 1. For daily ischemic stroke onsets, statistically negative associations were only observed among men and elders. In details, the percent decrease in daily ischemic stroke onsets with an IQR increase in $\mathrm{O}_{3}$ levels was $0.434 \%$ for men and $0.4 \%$ for elders. Moreover, the estimated effect of $\mathrm{O}_{3}$ was more significant in the cool season $(-0.845 \%, 95 \% \mathrm{CI}-1.361 \%$ to $-0.326 \%)$ than in the warm season $(-0.076 \%, 95 \% \mathrm{CI}$ $-0.398 \%$ to $0.246 \%$ ). As for daily ischemic stroke deaths, similarly, statistically negative associations were also found among men $(-1.040 \%, 95 \% \mathrm{CI}-1.612 \%$ to $-0.464 \%)$ and elders $(-0.697 \%, 95 \% \mathrm{CI}$ $-1.120 \%$ to $-0.273 \%)$. Moreover, the negative association in the cool season group $(-1.006 \%, 95 \% \mathrm{CI}$ $-1.839 \%$ to $-0.165 \%)$ was more pronounced than that in the warm season group $(-0.714 \%, 95 \% \mathrm{CI}$ $-1.203 \%$ to $-0.223 \%)$.
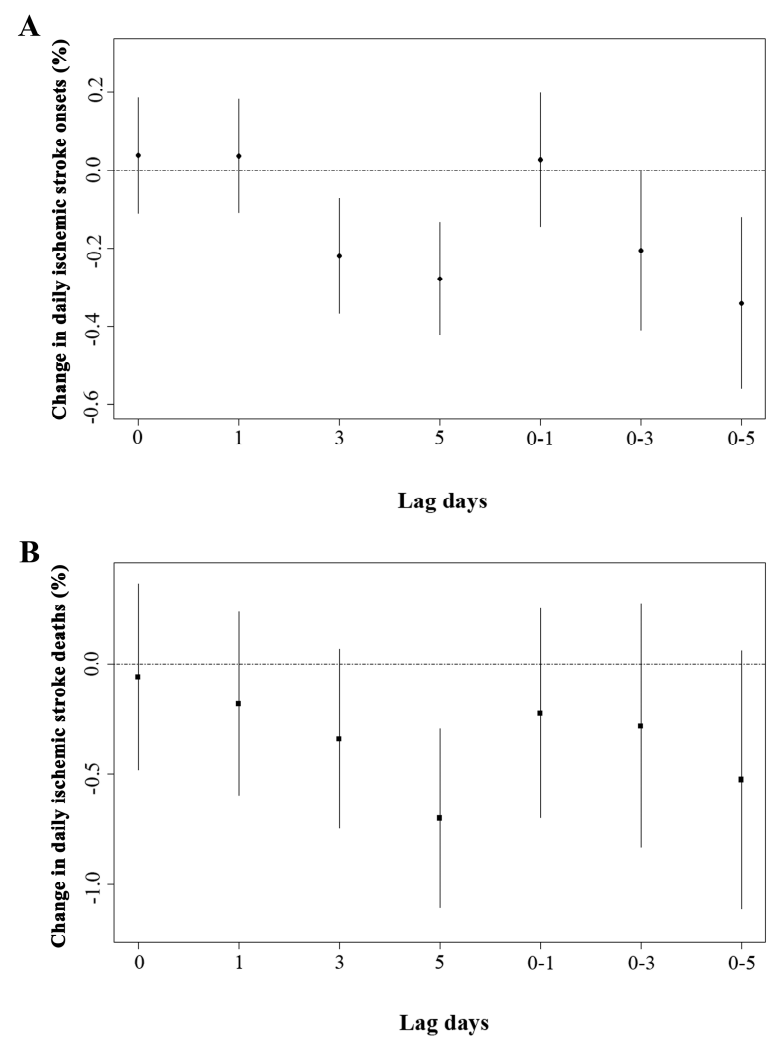

Figure 2. The percentage changes in daily ischemic stroke onsets (A) and deaths (B) with per interquartile range increment in $\mathrm{O}_{3}$ concentrations at different lag days in single-pollutant models in Changzhou, 2015-2016. The data was expressed as mean with 95\% confidence interval. $\mathrm{O}_{3}$ indicates ozone.

The exposure-response relationships of $\mathrm{O}_{3}$ levels with risk of ischemic stroke onsets and deaths were performed in Figure 3. The curve for daily ischemic stroke deaths was approximately linear negative (Figure 3B), whereas the smoothing spline for daily ischemic stroke onsets was negatively 
linear and flat at higher $\mathrm{O}_{3}$ levels (Figure 3A). Moreover, sensitivity analysis was also conducted in Figure 4. In both two-pollutant and multi-pollutant models, the effect estimates of $\mathrm{O}_{3}$ were stable for both daily ischemic stroke onsets (lag 0-5) (Figure 4A) and daily ischemic stroke deaths (lag 5) (Figure 4B).

Table 1. Subgroup analyses of the associations between ambient $\mathrm{O}_{3}$ levels and daily ischemic stroke onsets and deaths modifying by age, gender and seasons.

\begin{tabular}{ccc}
\hline Variables & Ischemic Stroke Onsets & Ischemic Stroke Deaths \\
\hline Total & $-0.340(-0.559,-0.120)^{\dagger}$ & $-0.697(-1.103,-0.290)^{\ddagger}$ \\
Age $\leq 65$ & $-0.098(-0.585,0.391)$ & $-0.615(-2.018,0.809)$ \\
Age $>65$ & $-0.400(-0.643,-0.157)^{\dagger}$ & $-0.697(-1.120,-0.273)^{\dagger}$ \\
Men & $-0.434(-0.738,-0.13)^{\dagger}$ & $-1.040(-1.612,-0.464)^{\ddagger}$ \\
Women & $-0.267(-0.584,0.051)$ & $-0.387(-0.960,0.188)$ \\
Cold Season & $-0.845(-1.361,-0.326)^{\dagger}$ & $-1.006(-1.839,-0.165)^{*}$ \\
Warm Season & $-0.076(-0.398,0.246)$ & $-0.714(-1.203,-0.223)^{\dagger}$ \\
\hline
\end{tabular}

The data was expressed as mean with $95 \%$ confidence interval, ${ }^{*} p<0.05,{ }^{\dagger} p<0.01,{ }^{\ddagger} p<0.001$.
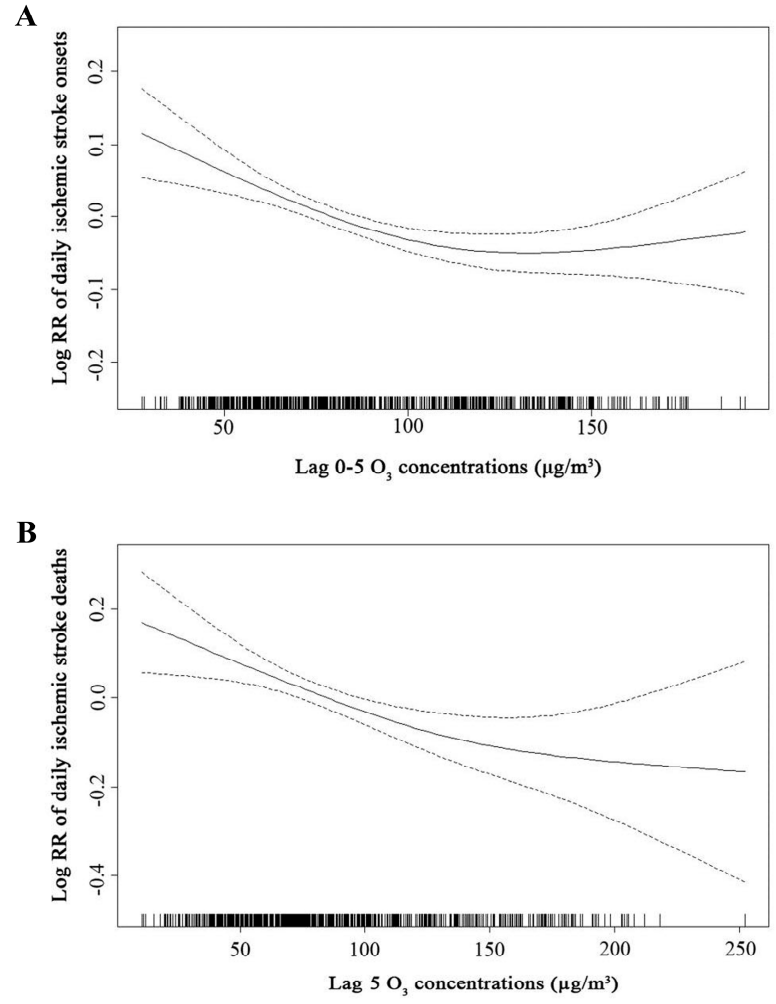

Figure 3. The exposure-response relationships of $\mathrm{O}_{3}$ levels with ischemic stroke onsets $(\mathbf{A})$ and deaths (B) at selected lag days (lag 0-5 for ischemic stroke onsets and lag 5 for daily ischemic stroke deaths) in single-pollutant models in Changzhou, 2015-2016. The data was expressed as mean with 95\% confidence interval. $\mathrm{O}_{3}$ indicates ozone. 
A

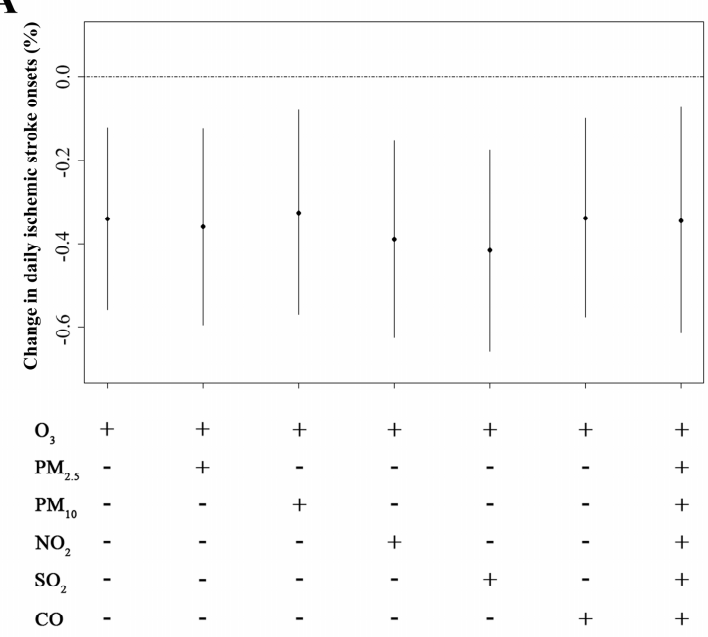

B

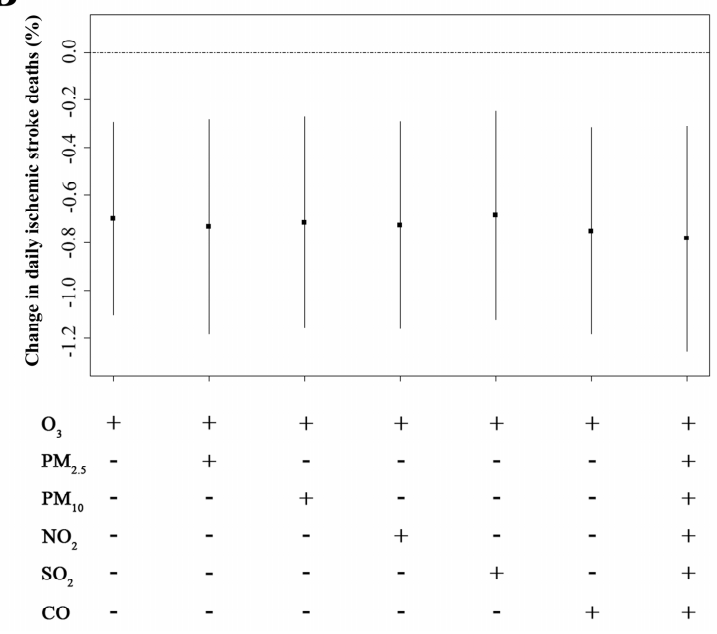

Figure 4. The percentage changes in daily ischemic stroke onsets (A) and deaths (B) with per interquartile range increment in $\mathrm{O}_{3}$ concentrations at selected lag days (lag 0-5 for ischemic stroke onsets and lag 5 for daily ischemic stroke deaths) in two-pollutant and multi-pollutant models in Changzhou, 2015-2016. The data was expressed as mean with $95 \%$ confidence interval. $\mathrm{O}_{3}$ indicates ozone; $\mathrm{PM}_{2.5}$, particulate matter that is $\leq 2.5 \mu \mathrm{m}$ in diameter; $\mathrm{PM}_{10}$, particulate matter that is $\leq 10 \mu \mathrm{m}$ in diameter; $\mathrm{NO}_{2}$, nitrogen dioxide; $\mathrm{SO}_{2}$, sulfur dioxide; $\mathrm{CO}$, carbon monoxide.

\section{Discussion}

In the present study, by recording 32,840 ischemic stroke counts and 4028 ischemic stroke-related deaths, negative associations between short-term ozone exposure and daily ischemic stroke onsets or deaths were identified in Changzhou from 9 January 2015 to 31 December 2016. The beneficial effects of $\mathrm{O}_{3}$ were more significant in men, elders ( $>65$ years) and cool season. The exposure-response curve for ischemic stroke onsets was sharply linear negative at low $\mathrm{O}_{3}$ levels $\left(<100 \mu \mathrm{g} / \mathrm{m}^{3}\right)$, suggesting that the low environmental $\mathrm{O}_{3}$ exposure might be beneficial more against ischemic stroke onsets and deaths. Moreover, the $\mathrm{O}_{3}$ related neuroprotective effect was independent of $\mathrm{PM}_{2.5}, \mathrm{PM}_{10}, \mathrm{SO}_{2}, \mathrm{NO}_{2}$ or $\mathrm{CO}$ exposure. Our results might have implications in preventing and treating ischemic strokes.

Previous epidemiological and clinical studies have presented incontrovertible and deleterious effects of ambient air pollutants (such as $\mathrm{PM}_{2.5}, \mathrm{NO}_{2}$ and $\mathrm{SO}_{2}$ ) on the morbidity and mortality of ischemic stroke $[9,20,21]$. However, in terms of $\mathrm{O}_{3}$, few studies assessed its cerebrovascular effects and no consensus has been reached. Although no statistical significance, several studies have demonstrated a negative association between average $\mathrm{O}_{3}$ levels and risk of strokes, which was consistent with our results. The estimate odds ratio (OR) for the association between ischemic stroke hospitalizations and $\mathrm{O}_{3}$ exposure was 0.98 in South Carolina and the OR for the association between previous day $\mathrm{O}_{3}$ increments and odds of recurrent stroke was 0.97 in Nueces County, Texas $[13,14]$. Moreover, as shown in a multicenter cohort study, adjusted OR of ischemic stroke for one standard deviation (SD) increase in $\mathrm{O}_{3}$ was 0.96 and men was more sensitive to the protector role of $\mathrm{O}_{3}(\mathrm{OR}=0.76)$ [22].

In ischemic strokes, the cerebral blood supply is depleted due to the embolisms or thrombosis [23]. Then the concentrations of blood oxygen and the formation of high energy phosphate compounds are dramatically decreased, leading to the depolarization, inflammation and apoptosis of the brains [24,25]. It has been reported that $\mathrm{O}_{3}$ oxidative preconditioning could attenuate ischemia/reperfusion induced hepatic and renal damages in rats. The enhanced expressions of eNOS and iNOS induced by $\mathrm{O}_{3}$ could improve and reestablish the balance of cellular redox [26,27]. $\mathrm{O}_{3}$ therapy was found to have extensive clinical applications in improving hemorheological parameters and oxygen delivery in patients with peripheral occlusive arterial disease [28]. In addition, the neuroprotective concentration-response curve for $\mathrm{O}_{3}$ was shaped as ' $\mathrm{U}$ ' with efficient level range of $80-120 \mu \mathrm{g} / \mathrm{mL}$ in rat models [17]. Thus, it is 
biologically plausible that within a selective concentration range, ambient $\mathrm{O}_{3}$ may exert neuroprotective effects against ischemic stroke onsets and deaths.

In this study, the protective effects of $\mathrm{O} 3$ on ischemic stroke onsets and deaths were found to be stronger in men than in women. Rather than vascular risk factors related differences between genders [29,30], the underlying reason for this observation might be the higher rate of ambient $\mathrm{O}_{3}$ exposure in men than in women due to longer time with outdoor working and laboring [31]. Thus, they are more likely to be exposed and affected by ambient $\mathrm{O}_{3}$. Moreover, the negative associations between air $\mathrm{O}_{3}$ levels and ischemic stroke onsets or deaths appeared to be more pronounced in elders than in young populations. Age is a nonmodifiable risk factor for ischemic stroke, and studies have indicated that ischemic tolerance is impaired in aged murine and human [32-34]. It has also been found that cerebral inflammation milieu is worse and the cerebrovascular hemodynamics is lower in elders than in young populations [35-37]. Therefore, elders are the plausibly sensitive subpopulations upon $\mathrm{O}_{3}$ exposure.

Season differences were also conducted in the current study. Because levels of air pollutants are variably depending on weather conditions, season is normally considered as a vital modifier in ambient air pollution related biological effects [38]. As a secondary pollutant, the formation of $\mathrm{O}_{3}$ requires nitrogen oxides, hydrocarbons and sunlight. Consequently, $\mathrm{O}_{3}$ levels are routinely higher in the warm season than in the cool season due to the increment of photochemistry (as shown in Figure 1). Furthermore, according to the concentration-response curves for both ischemic stroke onsets and deaths in this study, the negative associations were stronger at the $\mathrm{O}_{3}$ concentrations below the $100 \mathrm{\mu g} / \mathrm{m}^{3}$, a concentration range normally seen in cool season. Thus, it was reasonable that the protective effects for both ischemic stroke onsets and deaths were more significant in the cool season than in warm season.

Deleterious effects of air pollution on human cardio-cerebral vascular systems have been extensively reported. In a meta-analysis of 94 studies, an increment in levels of ambient pollutants was positively associated with increased admission for stroke or mortality stroke. The pooled relative risks were 1.011 for $\mathrm{PM}_{2.5}, 1.002$ for $\mathrm{PM}_{10}, 1.015$ for $\mathrm{CO}, 1.019$ for $\mathrm{SO}_{2}$ and 1.014 for $\mathrm{NO}_{2}$, respectively [39]. And the underlying mechanism by which air pollution exert as a risk factor for ischemic stroke might be that PMs and gaseous air pollutants, such $\mathrm{SO}_{2}$ and $\mathrm{NO}_{2}$ could activate astrocytes, disrupt synaptic functions and enhance endothelial and inflammatory responses of the brains [40-43]. Thus, to obtain more reliable and precise results, the potential air pollutants confounders should be taken into considerate. As shown in the sensitivity analysis, the estimated percent changes in daily ischemic stroke onsets and deaths with per IQR increment in $\mathrm{O}_{3}$ levels were coincident and stable in both two-pollutant model and multi-pollutant model, suggesting that the neuroprotective effect of $\mathrm{O}_{3}$ was reliable and independent from other air pollutants.

Several weaknesses of this study should be noted. Although air pollution data were collected from ten fixed-site monitoring stations, they could not be representative enough of individual exposure. Thus, exposure fallacy may exist. Furthermore, due to the retrospective design of this study, detailed population data respecting cigarette smoking, type of indoor home heating, residential mobility and other potential risk factors for ischemic stroke such as high blood pressure and obesity were limited. In addition, the results presented in this study should be interpreted with cautions. As the relationship between $\mathrm{O}_{3}$ exposure and decreased ischemic stroke risk may not equal to the cause-effect association. Further epidemiological studies (such as cohort study) are needed to explore the $\mathrm{O}_{3}$ related long-term effects. The current study also possessed several strengths. By identifying a crowd of ischemic stroke onsets and deaths, this study provides sufficient statistical power to evaluate the $\mathrm{O}_{3}$ related effects. Moreover, the acute protective effect of $\mathrm{O}_{3}$ on ischemic stroke was comprehensively assessed and the results are reliable and valuable in this study. 


\section{Conclusions}

In conclusion, the current population-based time-series study indicated that acute $\mathrm{O}_{3}$ exposure was associated with decreased risk of ischemic stroke. The neuroprotective effect was more robust in the cool season, and among women and elders.

Acknowledgments: This work was supported by the Natural Science Foundation of China (81502801), a project funded by the Priority Academic Program Development of Jiangsu Higher Education Institutions (2014), a collegiate Natural Science Foundations of Jiangsu province (16KJB330005), the science and technology support program funded by Changzhou Municipal Science and Technology Bureau (CE20145046) and the Science and Technique Foundation for Youths by Health and Family Planning Commission of Changzhou (QN201603).

Author Contributions: Zhan Zhang conceived and designed the study; Yongquan Yu, Huibin Dong, Shen Yao, Minghui Ji and Xingjuan Yao performed the study. Yongquan Yu and Shen Yao cleaned and analyzed the data; Yongquan Yu and Huibin Dong wrote the manuscript and interpreted the results. Zhan Zhang revised the manuscript. All authors read and approved the final manuscript.

Conflicts of Interest: The authors declare no conflict of interest.

\section{References}

1. Feigin, V.L.; Forouzanfar, M.H.; Krishnamurthi, R.; Mensah, G.A.; Connor, M.; Bennett, D.A.; Moran, A.E.; Sacco, R.L.; Anderson, L.; Truelsen, T.; et al. Global and regional burden of stroke during 1990-2010: Findings from the global burden of disease study 2010. Lancet 2014, 383, 245-254. [CrossRef]

2. Lozano, R.; Naghavi, M.; Foreman, K.; Lim, S.; Shibuya, K.; Aboyans, V.; Abraham, J.; Adair, T.; Aggarwal, R.; Ahn, S.Y.; et al. Global and regional mortality from 235 causes of death for 20 age groups in 1990 and 2010: A systematic analysis for the global burden of disease study 2010. Lancet 2012, 380, 2095-2128. [CrossRef]

3. Murray, C.J.; Vos, T.; Lozano, R.; Naghavi, M.; Flaxman, A.D.; Michaud, C.; Ezzati, M.; Shibuya, K.; Salomon, J.A.; Abdalla, S.; et al. Disability-adjusted life years (dalys) for 291 diseases and injuries in 21 regions, 1990-2010: A systematic analysis for the global burden of disease study 2010. Lancet 2012, 380, 2197-2223. [CrossRef]

4. Deb, P.; Sharma, S.; Hassan, K.M. Pathophysiologic mechanisms of acute ischemic stroke: An overview with emphasis on therapeutic significance beyond thrombolysis. Pathophysiology 2010, 17, 197-218. [CrossRef] [PubMed]

5. Fernandez-Lopez, D.; Natarajan, N.; Ashwal, S.; Vexler, Z.S. Mechanisms of perinatal arterial ischemic stroke. J. Cereb. Blood Flow Metab. 2014, 34, 921-932. [CrossRef] [PubMed]

6. Argacha, J.F.; Bourdrel, T.; van de Borne, P. Ecology of the cardiovascular system: A focus on air-related environmental factors. Trends Cardiovasc. Med. 2017. [CrossRef] [PubMed]

7. Wang, Y.; Eliot, M.N.; Wellenius, G.A. Short-term changes in ambient particulate matter and risk of stroke: A systematic review and meta-analysis. J. Am. Heart Assoc. 2014, 3, e00983. [CrossRef] [PubMed]

8. Qiu, H.; Sun, S.; Tsang, H.; Wong, C.M.; Lee, R.S.; Schooling, C.M.; Tian, L. Fine particulate matter exposure and incidence of stroke: A cohort study in Hong Kong. Neurology 2017, 88, 1709-1717. [CrossRef] [PubMed]

9. Liu, H.; Tian, Y.; Xu, Y.; Zhang, J. Ambient particulate matter concentrations and hospitalization for stroke in 26 Chinese cities: A case-crossover study. Stroke 2017, 48, 2052-2059. [CrossRef] [PubMed]

10. Bedada, G.B.; Smith, C.J.; Tyrrell, P.J.; Hirst, A.A.; Agius, R. Short-term effects of ambient particulates and gaseous pollutants on the incidence of transient ischaemic attack and minor stroke: A case-crossover study. Environ. Health 2012, 11, 77. [CrossRef] [PubMed]

11. Yang, W.S.; Wang, X.; Deng, Q.; Fan, W.Y.; Wang, W.Y. An evidence-based appraisal of global association between air pollution and risk of stroke. Int. J. Cardiol. 2014, 175, 307-313. [CrossRef] [PubMed]

12. Wing, J.J.; Sanchez, B.N.; Adar, S.D.; Meurer, W.J.; Morgenstern, L.B.; Smith, M.A.; Lisabeth, L.D. Synergism of short-term air pollution exposures and neighborhood disadvantage on initial stroke severity. Stroke 2017, 48, 3126-3129. [CrossRef] [PubMed]

13. Montresor-Lopez, J.A.; Yanosky, J.D.; Mittleman, M.A.; Sapkota, A.; He, X.; Hibbert, J.D.; Wirth, M.D.; Puett, R.C. Short-term exposure to ambient ozone and stroke hospital admission: A case-crossover analysis. J. Expo. Sci. Environ. Epidemiol. 2016, 26, 162-166. [CrossRef] [PubMed] 
14. Wing, J.J.; Adar, S.D.; Sanchez, B.N.; Morgenstern, L.B.; Smith, M.A.; Lisabeth, L.D. Short-term exposures to ambient air pollution and risk of recurrent ischemic stroke. Environ. Res. 2017, 152, 304-307. [CrossRef] [PubMed]

15. Shah, A.S.; Newby, D.E.; Mills, N.L. Potential link between ozone and recurrent stroke. Heart 2010, 96, 1953-1954. [CrossRef] [PubMed]

16. Sancak, E.B.; Turkon, H.; Cukur, S.; Erimsah, S.; Akbas, A.; Gulpinar, M.T.; Toman, H.; Sahin, H.; Uzun, M. Major ozonated autohemotherapy preconditioning ameliorates kidney ischemia-reperfusion injury. Inflammation 2016, 39, 209-217. [CrossRef] [PubMed]

17. Frosini, M.; Contartese, A.; Zanardi, I.; Travagli, V.; Bocci, V. Selective ozone concentrations may reduce the ischemic damage after a stroke. Free Radic. Res. 2012, 46, 612-618. [CrossRef] [PubMed]

18. Clavo, B.; Suarez, G.; Aguilar, Y.; Gutierrez, D.; Ponce, P.; Cubero, A.; Robaina, F.; Carreras, J.L. Brain ischemia and hypometabolism treated by ozone therapy. Forsch. Komplementmed. 2011, 18, 283-287. [CrossRef] [PubMed]

19. Xie, W.; Li, G.; Zhao, D.; Xie, X.; Wei, Z.; Wang, W.; Wang, M.; Li, G.; Liu, W.; Sun, J.; et al. Relationship between fine particulate air pollution and ischaemic heart disease morbidity and mortality. Heart 2015, 101, 257-263. [CrossRef] [PubMed]

20. Guo, P.; Wang, Y.; Feng, W.; Wu, J.; Fu, C.; Deng, H.; Huang, J.; Wang, L.; Zheng, M.; Liu, H. Ambient air pollution and risk for ischemic stroke: A short-term exposure assessment in South China. Int. J. Environ. Res. Public Health 2017, 14, 1091. [CrossRef] [PubMed]

21. Vidale, S.; Arnaboldi, M.; Bosio, V.; Corrado, G.; Guidotti, M.; Sterzi, R.; Campana, C. Short-term air pollution exposure and cardiovascular events: A 10-year study in the urban area of Como, Italy. Int. J. Cardiol. 2017, 248, 389-393. [CrossRef] [PubMed]

22. Mechtouff, L.; Canoui-Poitrine, F.; Schott, A.M.; Nighoghossian, N.; Trouillas, P.; Termoz, A.; Porthault-Chatard, S.; David, J.S.; Chasles, V.; Derex, L. Lack of association between air pollutant exposure and short-term risk of ischaemic stroke in Lyon, France. Int. J. Stroke 2012, 7, 669-674. [CrossRef] [PubMed]

23. Veltkamp, R.; Gill, D. Clinical trials of immunomodulation in ischemic stroke. Neurotherapeutics 2016, 13, 791-800. [CrossRef] [PubMed]

24. Doyle, K.P.; Simon, R.P.; Stenzel-Poore, M.P. Mechanisms of ischemic brain damage. Neuropharmacology 2008, 55, 310-318. [CrossRef] [PubMed]

25. Zhao, H.; Steinberg, G.K.; Sapolsky, R.M. General versus specific actions of mild-moderate hypothermia in attenuating cerebral ischemic damage. J. Cereb. Blood Flow Metab. 2007, 27, 1879-1894. [CrossRef] [PubMed]

26. Ajamieh, H.H.; Menendez, S.; Martinez-Sanchez, G.; Candelario-Jalil, E.; Re, L.; Giuliani, A.; Fernandez, O.S. Effects of ozone oxidative preconditioning on nitric oxide generation and cellular redox balance in a rat model of hepatic ischaemia-reperfusion. Liver Int. 2004, 24, 55-62. [CrossRef] [PubMed]

27. Chen, H.; Xing, B.; Liu, X.; Zhan, B.; Zhou, J.; Zhu, H.; Chen, Z. Ozone oxidative preconditioning protects the rat kidney from reperfusion injury: The role of nitric oxide. J. Surg. Res. 2008, 149, 287-295. [CrossRef] [PubMed]

28. Giunta, R.; Coppola, A.; Luongo, C.; Sammartino, A.; Guastafierro, S.; Grassia, A.; Giunta, L.; Mascolo, L.; Tirelli, A.; Coppola, L. Ozonized autohemotransfusion improves hemorheological parameters and oxygen delivery to tissues in patients with peripheral occlusive arterial disease. Ann. Hematol. 2001, 80, 745-748. [CrossRef] [PubMed]

29. Cordonnier, C.; Sprigg, N.; Sandset, E.C.; Pavlovic, A.; Sunnerhagen, K.S.; Caso, V.; Christensen, H. Stroke in women-From evidence to inequalities. Nat. Rev. Neurol. 2017, 13, 521-532. [CrossRef] [PubMed]

30. Hart, J.E.; Puett, R.C.; Rexrode, K.M.; Albert, C.M.; Laden, F. Effect modification of long-term air pollution exposures and the risk of incident cardiovascular disease in us women. J. Am. Heart Assoc. 2015, 4, e002301. [CrossRef] [PubMed]

31. Qiu, H.; Yu, I.T.; Wang, X.; Tian, L.; Tse, L.A.; Wong, T.W. Cool and dry weather enhances the effects of air pollution on emergency IHD hospital admissions. Int. J. Cardiol. 2013, 168, 500-505. [CrossRef] [PubMed]

32. Abete, P.; Cacciatore, F.; Testa, G.; Della-Morte, D.; Galizia, G.; de Santis, D.; Calabrese, C.; Cioppa, A.; Ferrara, N.; Rengo, F. Ischemic preconditioning in the aging heart: From bench to bedside. Ageing Res. Rev. 2010, 9, 153-162. [CrossRef] [PubMed] 
33. Ishihara, M.; Sato, H.; Tateishi, H.; Kawagoe, T.; Shimatani, Y.; Ueda, K.; Noma, K.; Yumoto, A.; Nishioka, K. Beneficial effect of prodromal angina pectoris is lost in elderly patients with acute myocardial infarction. Am. Heart J. 2000, 139, 881-888. [CrossRef]

34. Peart, J.N.; Pepe, S.; Reichelt, M.E.; Beckett, N.; See Hoe, L.; Ozberk, V.; Niesman, I.R.; Patel, H.H.; Headrick, J.P. Dysfunctional survival-signaling and stress-intolerance in aged murine and human myocardium. Exp. Gerontol. 2014, 50, 72-81. [CrossRef] [PubMed]

35. Agarwal, S.; Scoffings, D.J.; Jones, P.S.; Marrapu, S.T.; Barry, P.J.; O’Brien, E.W.; Baron, J.C.; Warburton, E.A. Interaction of age with the ischaemic penumbra, leptomeningeal collateral circulation and haemodynamic variables in acute stroke: A pilot study. J. Neurol. Neurosurg. Psychiatry 2013, 84, 271-276. [CrossRef] [PubMed]

36. Giantin, V.; Semplicini, A.; Franchin, A.; Simonato, M.; Baccaglini, K.; Attanasio, F.; Toffanello, E.D.; Manzato, E. Outcome after acute ischemic stroke (AIS) in older patients: Effects of age, neurological deficit severity and blood pressure (BP) variations. Arch. Gerontol. Geriatr. 2011, 52, e185-e191. [CrossRef] [PubMed]

37. Leira, R.; Millan, M.; Diez-Tejedor, E.; Blanco, M.; Serena, J.; Fuentes, B.; Rodriguez-Yanez, M.; Castellanos, M.; Lago, A.; Davalos, A.; et al. Age determines the effects of blood pressure lowering during the acute phase of ischemic stroke: The TICA study. Hypertension 2009, 54, 769-774. [CrossRef] [PubMed]

38. Tong, L.; Li, K.; Zhou, Q. Season, sex and age as modifiers in the association of psychosis morbidity with air pollutants: A rising problem in a Chinese metropolis. Sci. Total Environ. 2016, 541, 928-933. [CrossRef] [PubMed]

39. Shah, A.S.; Lee, K.K.; McAllister, D.A.; Hunter, A.; Nair, H.; Whiteley, W.; Langrish, J.P.; Newby, D.E.; Mills, N.L. Short term exposure to air pollution and stroke: Systematic review and meta-analysis. BMJ 2015, 350, h1295. [CrossRef] [PubMed]

40. Guo, L.; Li, B.; Miao, J.J.; Yun, Y.; Li, G.K.; Sang, N. Seasonal variation in air particulate matter $\left(\mathrm{PM}_{10}\right)$ exposure-induced ischemia-like injuries in the rat brain. Chem. Res. Toxicol. 2015, 28, 431-439. [CrossRef] [PubMed]

41. Sang, N.; Yun, Y.; Li, H.; Hou, L.; Han, M.; Li, G. $\mathrm{SO}_{2}$ inhalation contributes to the development and progression of ischemic stroke in the brain. Toxicol. Sci. 2010, 114, 226-236. [CrossRef] [PubMed]

42. Zhu, N.; Li, H.; Han, M.; Guo, L.; Chen, L.; Yun, Y.; Guo, Z.; Li, G.; Sang, N. Environmental nitrogen dioxide $\left(\mathrm{NO}_{2}\right)$ exposure influences development and progression of ischemic stroke. Toxicol. Lett. 2012, 214, 120-130. [CrossRef] [PubMed]

43. Zhang, C.; Meng, Q.; Zhang, X.; Wu, S.; Wang, S.; Chen, R.; Li, X. Role of astrocyte activation in fine particulate matter-enhancement of existing ischemic stroke in sprague-dawley male rats. J. Toxicol. Environ. Health A 2016, 79, 393-401. [CrossRef] [PubMed]

(C) 2017 by the authors. Licensee MDPI, Basel, Switzerland. This article is an open access article distributed under the terms and conditions of the Creative Commons Attribution (CC BY) license (http:/ / creativecommons.org/licenses/by/4.0/). 